\title{
LAMP1 Gene
}

National Cancer Institute

\section{Source}

National Cancer Institute. LAMP1 Gene. NCI Thesaurus. Code C104627.

This gene is involved in cell adhesion and may be involved in tumor cell metastasis. 